\title{
Developing Teaching Material on Non-literary Text Writing with Story Writing Map Strategy
}

\author{
A Sedyoko $^{1}$, B Nurgiyantoro $^{2}$ \\ ${ }^{1,2}$ Yogyakarta State University \\ \{ardasedyoko@gmail.com¹,burhan@uny.ac.id²
}

\begin{abstract}
This study aims to produce teaching material for writing non-literary texts with a Story Writing Map strategy for high school students in class X and knowing the feasibility of the product regarding the results of validation by experts, teachers, and students. This development research uses the development steps of Borg \& Gall (1983), namely needs analysis, product planning, initial product development, expert and teacher validation, first product revisions, student response trials, second product revisions, and final products. Needs analysis was carried out in Klaten Regency, namely at SMAN 2 Klaten, SMAN 1 Karanganom, and SMAN 1 Jatinom. The product trial was conducted by 30 grade $\mathrm{X}$ students at SMAN 2 Klaten. Teaching materials for writing non-literary texts are developed based on the revised edition of the 2013 curriculum, which consists of three non-literary text writing material, namely observation report text, exposition text, and biographical texts. The results of the study showed that the writing materials developed had a decent category of use. Based on expert judgment, the teaching material produced has a very good category, regarding the feasibility of content, language, presentation, and graphics. Based on the teacher's assessment, the teaching material developed has categories both regarding the feasibility of content, language, and graphics, while the feasibility aspect of presenting these teaching materials is categorized very well. Based on the student response test, the teaching material for writing non-literary texts is categorized very well.
\end{abstract}

Keywords: Teaching Materials, Writing, Non-Literary Text, Story Writing Map Strategies

\section{INTRODUCTION}

Learning Indonesian is always associated with four aspects of language skills, including listening, speaking, reading and writing. The four aspects have an attachment to learning from one another. Writing is a form of manifestation of language competence most recently mastered by language learners after the competence of listening, speaking, and reading [1]. Thus, writing is an aspect of language skills that must involve the other three elements in the aspects of existing language skills. It can be said that writing skill is the most challenging language skill compared to other language skills.

To learn a variety of language skills, language learning material is needed. Language learning material includes textbooks, student workbooks, tapes, LPs, video recordings, photocopied documents, newspapers, and others [2]. Of the many learning materials available, 
the book has a significant contribution. With books, the process of implementing education will be more natural because teachers can manage learning activities effectively and efficiently [3]. Moreover, textbooks play an essential role in the teaching and learning process because books are the primary agents in conveying knowledge to students [4].

Students can learn best when they have good textbooks. It is because book becomes a vehicle for students to understand the requirements of learning material which are the representations of the curriculum. With various competency requirements, Indonesian textbooks circulate in the community, both issued by the government and by the private sector, they directly contain four aspects of language skills. Thus, one problem surfaced, namely that there had not been found any Indonesian textbook published by the government and also by the private sector which focused on learning one language skill, especially writing skill.

Teaching is the process of transforming content knowledge into active pedagogical forms [5]. It means that as a teacher in teaching language skills must be able to translate knowledge that comes from communicative teaching materials to his/her students. Teaching materials that are mainly used in learning are textbooks. With the existence of textbooks, the teacher must be able to actively adjust the contents of the book to the learning needs. Thus, the development of teaching materials that lead to the effectiveness and utilization of the teaching and learning process needs to be done.

Based on the description above, research and development are needed regarding teaching materials that focus on discussing one language skill. Teaching materials developed in this study are teaching materials on writing skills. The teaching material on writing developed in this research was focused on non-literary texts. It is because it is still rare to find Indonesian language teaching materials that focus on non-literary writing learning. In this case, the teaching material is different from existing literary text teaching materials which are always integrated into writing skills.

Textbooks that are used as teaching materials should be able to communicate the materials and convey information using various learning methods so that each student can absorb and understand it for later use [3]. In line with this statement, the development of teaching materials for writing non-literary texts was developed with a learning strategy. The learning strategy used in developing the teaching materials in this research is the Story Writing Map strategy.

Story Writing Map strategy is a learning strategy on writing that emphasizes at the prewriting stage. It is a prewriting strategy which increases students organizational skills and helps them to identify and understand the elements of a story [6]. This strategy can assist students in organizing their thoughts into a whole story chart. With the implementation of this strategy into writing activities, students are triggered to be as creative as possible to write a piece of writing that will be produced. Also, this strategy also helps students to be able to develop the goals of each text they provide.

\section{RESEARCH METHOD}

Development model used in this research is Research and Development (R \& D). This research used the development procedure of Borg \& Gall [7] with several modifications, namely (1) needs analysis, (2) product planning, (3) initial product development, (4) expert and teacher validation, (5) initial product revision, (6) students' response measurement, (7) second product revisions, and (8) final products. Needs analysis was carried out in Klaten Regency, at SMAN 2 Klaten, SMAN 1 Karanganom, and SMAN 1 Jatinom. There were 30 students from $10^{\text {th }}$ grade of SMA N 2 Klaten participated in the product test. 
This research had two types of data, namely quantitative and qualitative data. Quantitative data was obtained from the assessment carried out by expert lecturers, teachers, and students, while qualitative data was obtained from the results of interviews and input in the form of criticism and suggestions by teachers and students. Also, qualitative data was also obtained from validators' data.

The data instruments used were questionnaires which consisted of a questionnaire of teacher's need analysis, a questionnaire of student's needs analysis, expert validation sheets, teacher validation sheets, and students' response sheets. These data were then used as a reference for the development of teaching materials and tools to determine the quality of teaching materials under study.

\section{RESULTS AND DISCUSSION}

The product of the Research and Development is in the form of teaching materials for writing non-literary texts for the $10^{\text {th }}$ grade Senior High School with a Story Writing Map strategy. This teaching material consists of an introduction, contents, and closing sections. The opening is in the form of covers, introductory words, instructions for using the book, charts of material presentation, table of contents, and at a glance of the Story Writing Map strategy. The content section contains material for writing non-literary texts consisting of three lessons, namely the subject matter of writing the text of the report on observation, exposition text, and biographical texts. Each document describes the material's exposure and required steps for writing non-literary text with the Story Writing Map strategy. In the end, there is a bibliography, glossary, index, and information about the author.

The data analysis of product validation is done by converting quantitative data into qualitative data. Changing this data is intended to determine the feasibility of the product being developed. The details are presented in Table 1 which serves as guidelines for interpreting the results of data analysis [8].

Table 1: Guidelines for Interpreting the Results of Data Analysis

\begin{tabular}{ccc}
\hline No. & Percentage & Qualification \\
\hline 1. & $81-100 \%$ & Very Good \\
2. & $61-80 \%$ & Good \\
3. & $41-60 \%$ & Average \\
4. & $21-40 \%$ & Poor \\
5. & $0-20 \%$ & Very Poor \\
\hline
\end{tabular}

\subsection{Results of validation by experts and teachers}

The developed products' assessment is based on aspects of content feasibility, language feasibility, presentation feasibility, and graphic feasibility. Criteria of content feasibility includes: (a) Inclusiveness and depth of materials by core competencies and basic competencies; (b) The selection of discourse, text, images, and illustrations by the competencies that must be achieved and useful for fulfilling students' curiosity; (c) Concepts and theories are in accordance to systematics of the knowledge; (d) Training, assignment, and assessment by the demands of authentic assessment; (e) Accuracy in applying the principle of language skills based on language theory. 
Criteria of language feasibility includes: (a) Conformity with the level of students' intellectual development and social-emotional development; (b) Message readability and language accuracy; (c) Adherence and integration, both chapters and paragraphs; (d) Material submission through paragraph development is carried out effectively.

Criteria of presentation feasibility includes: (a) Systematic consistency of presentation, conceptual conclusions, and balance between the chapters; (b) Centering Story Writing Map strategy in the developed instructional materials; (c) Stimulate student metacognition (spiritual attitude and emotional attitude); (d) Stimulate students' imagination, creation, and critical thinking (knowledge and skills).

Criteria of graphics feasibility includes: (a) Layout that contains material exposures, examples, and activities that students must do is presented proportionally, according to the size of the book; (b) Presentation of cover, illustration, and image can support students 'curiosity to increase their learning motivation.

Based on validation by experts, the content feasibility aspect gets scores $85.33 \%$ with the criteria of "very good." The language feasibility gets a score of $85 \%$ with the criteria of "very good." Presentation feasibility gets a score of $81.67 \%$ with the criteria of "very good", and the graphics feasibility gets a score of $90 \%$ with "very good" criteria. Thus, in average, the overall product validation carried out by experts scored $85.5 \%$ (or "very good").

Based on validation by teachers, it can be seen that the content feasibility aspect gets scores $77.6 \%$ with the criteria of "good." The language feasibility scores $76 \%$ with the criteria of "good." The presentation feasibility gets a score of $81 \%$ with the criteria of "very good." Additionally, the graphics feasibility gets a score of $80 \%$ with "very good" criteria. Thus, in average, the overall product validation carried out by teachers score $78.65 \%$ (or "good").

\subsection{Students' response results}

After the teaching materials have been validated by experts and by Indonesian teachers, the researcher made revisions according to experts' and teachers' suggestions and criticisms. The teaching materials are ready to be tested to students. Students act as respondents by filling out Students' Response sheet. Assessment made by the students is done with a range of scores 15. This assessment is carried out by 30 students. After evaluating the percentage, students' responses to the developed instructional materials obtained a score of $86.27 \%$. Therefore, teaching materials for writing non-literary texts for $10^{\text {th }}$ grade senior high school students with the Story Writing Map strategy are categorized as "very good."

Criteria of students' response includes: (a) Inclusiveness and depth of material by core competencies and basic competencies; (b) The selection of discourse, text, images, and illustrations by the competencies that must be achieved and useful for fulfilling students' curiosity; (c) Selection of examples by the competencies that must be achieved; (d) Training, assignment, and assessment are by the demands of authentic assessment; (e) The material is explained communicatively; (f) The use of language by the level of students' intellectual development and social-emotional development; (g) Message readability and language accuracy; (h) Adherence and integration, both chapters and paragraphs; (i) Submission of material through paragraph development is carried out effectively; (j) Systematic consistency of presentation, conceptual conclusions, and balance between the chapters; (k) Centering Story Writing Map strategy in the developed instructional materials; (l) Stimulate students' metacognition (spiritual attitude and emotional attitude); (m) Stimulate students' imagination, creation, and critical thinking (knowledge and skills); (n) Layout that contains material exposures, examples, and activities that students must do is presented proportionally, 
according to the size of the book; (o) Presentation of cover, illustration, and picture can support students 'curiosity to increase their learning motivation.

\subsection{Discussion}

\subsubsection{Product planning and development}

The Story Writing Map strategy is integrated to preparation of teaching materials with the aim of increasing the ability to organize students' writing to be more systematic. Mind Mapping strategy can help students to organize their ideas effectively, understand topics and written information easily [9]. So that, students can develop or describe concepts more effectively. There are eight steps in applying Story Writing Map strategy, namely determining ideas, settling ideas, illustrating content, combining content, summarizing goals, compiling texts, presenting works, and publishing works.

The developed teaching materials are in the form of book. The teaching material book is prepared for the learning process that contains materials or subject matters to be taught [10]. The developed teaching materials consist of nine parts, namely cover, preface, instructions for using the book, material presentation chart, table of contents, learning material, glossary, index, and about the author.

Each learning text in these materials contains several aspects. First, it is always preceded by the cover of the chapter or the title of the learning material that is studied with illustrated images aligned with the characteristics of the text. After the cover page of the second chapter, a material's mapping chart is presented and comprises a content framework for each learning text. Third, it comprises learning materials that include an introduction to the text, text structure, and grammatical rules. Fourth, it includes steps to write a text using Story Writing Map strategy. Fifth, final section presents a scoring rubric. Scoring rubrics are used to determine the writing scores by evaluating aspects, like, grammar, vocabulary, writing mechanics, written organization and context [11].

The focus of developing non-literary text teaching materials is in the text writing strategy section using Story Writing Map strategy. The following is the description. First, students must determine which ideas will be developed as the central of the entire text. The concept developed must be in harmony with the characteristics of the text to be produced.

Second, students begin to settle ideas. It aims to reflect on whether the concept to be developed is interesting to discuss. Also, this stage is the stage for thinking about supporting data that will build the entire text.

Third is the preliminary stage. This initial stage includes three stages, namely illustrating the content, combining the contents, and concluding the goal. In illustrating the content, a predetermined idea begins to be described in some statements that represent ideas and also problems in the text to be produced. These statements are manifested in several sentences. Sentences that express the design can be referred to as the content frame of the text.

In illustrating the content, students begin to develop each statement demonstrating the content with supporting dictionaries. These supporting dictionaries are associating ideas which, if described, will become a whole unit in the form of paragraphs. The dictionaries must be able to explain the statements that have been made previously. Thus, at this stage, students must pay attention to cohesiveness requirements in a paragraph, namely cohesion and coherence. 
The last point at the prewriting stage is conclusion of the goal. It contains statements about the purpose of the text production. This section is an essential point for students to inform the reader, the core of the text that is to be produced.

Fourth, the stages of assembling of text. At this stage, students can begin to assemble the whole idea from the process of illustrating the contents, combining content, and concluding the goal into one complete text. This series must pay attention to the structure of the text to be produced. Besides, students must pay attention to the effectiveness of the written sentences and also comply with the General Indonesian Spelling Guidelines.

Fifth is the stage of work presentation. The exhibition of the work can be said to be a performance or directly to expose the writing that has been produced by being reviewed by a colleague or to be read in front of the class. Hence, students will get comments on the text that has been produced. These comments are used as a material for consideration, whether or not students will revise the text that has been made.

Sixth is the stage of work publication. This is the final stage. After students can produce text independently and reviewed by colleagues, students can publish their work in both print and electronic media, even in the mass media.

\subsubsection{Product validation results}

Product validation is divided into two parts; carried out by experts and teachers, and then by product users or students. The first validation was carried out by three experts and five teachers in three schools in Klaten Regency, namely at SMAN 1 Karanganom, SMAN 1 Jatinom, and SMAN 2 Klaten. After completing and revising according to given suggestions and criticisms, the product was tested on students to see their responses regarding the feasibility of the developed teaching materials.

Based on the assessment from experts, teachers, and also students, it can be concluded that the developed teaching materials is in the category of "very good." Thus, the teaching material is suitable for students to use as a supplementary book in learning activities to write non-literary texts. Also, the developed teaching materials can help teachers in selecting alternative teaching materials in learning to write non-literary texts. Table 2 shows an overall result of experts', teachers', and students' validation on the developed teaching materials.

Table 2: The Result of Experts', Teachers', and Students' Validation

\begin{tabular}{llll}
\hline Interviewes & Rated Aspect & Percentage & Feasibility Level \\
\hline Experts & Content & 85,33 & Very Good \\
& Language & 85 & Very Good \\
& Presentation & 81,67 & Very Good \\
\multirow{4}{*}{ Teachers } & Graphics & 90 & Very Good \\
& Content & 77,6 & Good \\
& Language & 76 & Good \\
& Presentation & 81 & Very Good \\
Students & Graphics & 80 & Good \\
Overall Percentage & 86,27 & Very Good \\
\hline
\end{tabular}




\section{CONCLUSIONS}

Based on the results of the validation by experts, teachers, and students, the developed teaching material comes into "very good" category. It is evidenced by the overall average percentage by $83.23 \%$, concerning content feasibility, language feasibility, presentation feasibility, and graphics feasibility. Therefore, the developed teaching material can be used as an alternative supplementary book in learning to write non-literary texts among $10^{\text {th }}$ grade senior high school students.

\section{REFERENCES}

[1] B. Nurgiyantoro, Penilaian Pembelajaran Bahasa Berbasis Kompetensi. Yogyakarta: BPFE, 2016.

[2] T. Brian, Materials Development in Language Teaching. New York: Cambride University Press, 1998.

[3] M. Muslich, Text Book Writing: Dasar-Dasar Pemahaman, Penulisan, dan Pemakaian Buku Teks. Yogyakarta: Ar-Ruzz Media, 2010.

[4] M. M. Abdelwahab, "Developing an English Language Textbook Evaluative Checklist," vol. 1, no. 3, pp. 55-70, 2013.

[5] K. Hyland, Second Language Writing. Cambridge: Cambridge University Press, 2004.

[6] D. K. Wiesendanger, Strategies for Literacy Education. New Jersey: Alfred University, 1996.

[7] W. R. Borg and M. D. Gall, Educational Research an Introduction, Fourth Edi. New York \& London: Longman, 1983.

[8] Riduwan, Skala Pengukuran Variabel-Variabel Penelitian. Bandung: Alfabeta, 2015.

[9] M. Yunus and C. H. Chien, "The Use of Mind Mapping Strategy in Malaysian University English Test ( MUET ) Writing," no. April, pp. 619-626, 2016.

[10] A. Prastowo, Panduan Kreatif Membuat Bahan Ajar Inovatif. Yogyakarta: Diva Press, 2012.

[11] A. Ghazali, Pembelajaran Keterampilan Berbahasa dengan Pendekatan KomunikatifInteraktif. Bandung: Refika Aditama, 2010. 